\title{
A Research on Promoting Non-English Majors' Learner Autonomy through Meta-cognitive Strategy Training in Higher Vocational Colleges
}

\author{
Lu Chen \\ Huanghe Science and Technology College \\ Zhengzhou, China
}

\begin{abstract}
Researchers have been aware that learner autonomy is crucial in improving learning efficiency. Chinese researchers have done lots of researches to explore the training mode of learner autonomy, but empirical researches on classroom-based learning context are far from enough. Chinese vocational students have their unique features. Their varying English backgrounds result in various learning needs which cause great difficulties to college English teaching. Promoting vocational students' learner autonomy can help combine their inside class English learning with outside class English learning. Meta-cognitive strategies are defined as higher executive skills that may entail planning, monitoring, and evaluating the success of a learning activity. It is apparent that meta-cognitive strategies are consistent with learner autonomy in core concepts. So this research aims to explore how to improve vocational students' learner autonomy through meta-cognitive strategy training.
\end{abstract}

Keywords-meta-cognitive training; learner autonomy; vocational students

\section{INTRODUCTION}

\section{A. Background and Statement of the Problem}

With the fast development of information technology, lifelong learning has already been a trend and living need for human beings. Learner autonomy is essential for life-long learning. The objective of "to enhance students' ability to study independently" in College English Curriculum Pedagogical Requirement (2007) well explains the necessity to cultivate learner autonomy in College English Teaching.

Learner autonomy has spread to China in 1980s. Based on studies abroad and at home, some Chinese scholars have implemented some teaching practices to facilitate learner autonomy. These researches gain outcomes and also bring in new questions.

First, the arising numbers of the definitions of learner autonomy have caused a vague understanding of the concept and have made it hard for practitioners and researches to pursue their researches in this area. As many different examining ways are applied to foster learner autonomy, a clear

Fund Project: This essay is the research findings of the project in 2014 named " The Strategy Study on Cultivation of Foreign Language Talents in Universities of Henan Province"; This project belongs to the Science and Technology Department of Henan Province, and its project number is 142 400410601 . operational definition is not completed.

Second, Meta-cognitive strategy training is one of the most-widely used methods to promote learner autonomy. It proves effective in enriching students' meta-cognitive knowledge, in developing good attitudes towards learning and promoting learner autonomy. But few training programs have achieved desired results. Students show little improvement in monitoring and regulating. Furthermore, how to well combine meta-cognitive strategy training inside and outside class is still a question which needs further studying.

At the same time many researches center on theoretical analysis, but how to promote students' learner autonomy efficiently is still lack of systematic theories supported by empirical researches.

\section{B. Research Questions}

In Vocational classes it is easily found that Students' English Levels vary a lot. Usually in some Vocational classes, almost one third of the students hardly have any English knowledge. They are far behind their classmates, but don't have enough determination and good learning strategies to catch up. Meantime, Vocational classes are always big, so the teacher usually can not cater to all the students' English learning needs, which causes teaching inefficiency. Students with poor English levels always give up English learning gradually. So it is necessary and important to study how to improve vocational students' learner autonomy and help them learn English inside and outside class.

So in this research, through one term's meta-cognitive strategy training the author attempts to figure out the following questions: 1) Does meta-cognitive training lead to vocational students' learning proficiency? 2) Does meta-cognitive strategy training result in vocational students' higher metacognitive strategy use? 3) Is meta-cognitive strategy training effective in facilitating vocational students' learner autonomy? 


\section{LITERATURE REVIEW OF SELF-AUTONOMY AND RELATED THEORIES}

\section{A. Definition of Learner Autonomy}

The concept of learner autonomy originated from the European political unrest of the 1960s which supported the individual freedom. Learner autonomy began with the reforms of adult education in the1960s. 1n 1981, with the publishing of Henri Holec's "Autonomy and Foreign Language Learning", the term "learner autonomy" has partly become the mainstream of language learning. Dickinson (1987), Little (1991), Kenny (1993), Benson and Voller (1997), Boud (1988), etc have all defined learner autonomy in different ways. There are ongoing debates in this field and the definitions are continuing to mature as more researches take place. Let's review some representative definitions and try to get insights into what learner autonomy is and what it consists of.

Holec has been a major influence in the debate about autonomy in language learning. By 1981 Holec (1981) had defined autonomy as "the ability to take charge of one's own learning", explaining that this ability "is not inborn but must be acquired either by natural means or by formal learning, i.e. in a systematic, deliberate way", and he further explains: "to take charge of one's own learning is to have, and to hold, the responsibility for all the decisions concerning all aspects of this learning", which includes: "determining the objectives; defining the contents and progressions; selecting the methods and techniques to be used; monitoring the procedures of acquisition; evaluating what has been acquired"(Holec, 1981:3).

Dickinson (1987) accepts the definition of autonomy as a "situation in which the learner is totally responsible for all of the decisions concerned with this learning and the implementation of those decisions" and also "where the learner takes responsibility for his learning and undertakes all the management tasks concerning with it".

The above definitions deal with the concept of learner autonomy from different perspectives. But some common points are all referred to. The first one is learner's positive attitude that the learner should be responsible for what he or she is learning. This shift of responsibility from teachers to students request the organizing of curriculum be more learnercentered and the change of distributions of rights between teachers and learners. The second one is the learner's capability. Autonomous learning definitely involves the learners' capability of using a set of strategies in the whole learning process.

\section{B. Variables Affecting Learner Autonomy}

Autonomous learning is affected not only by learners' internal elements, but also by external environment. Internal elements mainly consist of learners' beliefs, motivations, learning strategies, capabilities, genders, affection features; External environment mainly includes learners' schools, families and social cultural background (He, Fu, Fang, Min, 2011). The following part will focus on the two basics: learners' beliefs and attitudes as well as learning strategies.
1) Learners' Beliefs and Attitudes: Learners' beliefs are of importance in fostering learner autonomy, because they are part of underlying mechanisms of meta-cognition which affect learners' planning, monitoring, accessing in learning process (Flavell, 1987: Wenden, 1998). In order to promote learner autonomy teachers should prepare their students to accept more responsibilities for their learning than they are accustomed to. Teachers need to be sensitive to their own beliefs and attitudes as the first step in becoming aware of the changes of their roles when fostering students' learner autonomy.

2) Learning Strategies and Learner Autonomy: Holmes \& Ramos(1991) believe learners should be encouraged to learn autonomously and made to be aware of some useful learning strategies in order to become capable autonomous learners. Cohen (1998) makes a link between learner autonomy and learning strategies. He claims that explicitly teaching learning strategies to students would “enhance students' efforts to reach language program goals because it encourages students to find their own pathways to success, and thus it promotes learner autonomy and self-direction" (Cohen, 1998:67). White (1995:209) argues that "the ability to exercise autonomy requires the learner to have developed an understanding of the nature of language learning of his or her role in that process, and as part of this to have an appropriate repertoire of language learning strategies". She (White, 1995:217) believes that meta-cognitive strategies are closely related to learner autonomy. She suggests that "autonomy in language learning results from the way in which, and the extent to which, the learner manages his or her interactions with the target language, rather than from the use of any specific set of cognitive strategies".

Generally, there is a consensus that "the use of learner strategies can lead to enhanced autonomy" (Cohen, 2007:44). From meta-cognitive strategy theories in chapter three, we can see learning strategy's relevance to learner autonomy.

\section{Approaches of Promoting Learner Autonomy}

Benson (2001:109) said "any practice that encourages and enables learners to take greater control of any aspect of learning can be considered as a means of fostering autonomy". He (Benson, 2001: 131) distinguishes between six types of practices fostering the development of autonomy, including resource-based approaches, technology-based approaches, learner-based approaches, classroom-based approaches, curriculum-based approaches, and teacher-based approaches.

Generally, different emphasis is placed on different aspects of control in the six approaches discussed above. Classroombased approaches attempt to foster autonomy by providing opportunities for students to make decisions regarding their learning within classroom context where they can collaborate with peers and make use of support from teachers. Major forms of classroom-based approaches include cooperative learning, profiles, self-assessment and peer-assessment. Learner-based approaches emphasize the direct production of behavioral and psychological changes in the learner that will 
enable learners to take greater control over their learning (Benson, 2005:142). Strategy training is the main form of these approaches. The common seen ways to implement strategy training are comprised of two aspects: cognitive strategy training, and meta-cognitive strategy training. The former is to inform students of the learning skills concerning listening strategies, communicative strategies, writing strategies, translation strategies and so on. The latter is to help students form the habit of making plans, choosing proper learning strategies and tasks, monitoring learning process, and evaluating learning outcomes so as to cultivate autonomous learners (Wang Duqin, 2002).

So classroom-based approaches and learner-based approaches are involved in this research. The following research focuses on the effectiveness of meta-cognitive strategy training in promoting learner autonomy on vocational students.

\section{THEORETICAL FRAMEWORK}

\section{A. Meta-Cognitive Strategy and Learner Autonomy}

Meta-cognitive strategies are closely related with autonomy. From the definition, we know learner autonomy emphasis taking charge of learning that learners employ in order to manager the planning, organization, and evaluation of their learning. On the other hand, meta-cognitive strategies involve "thinking about the learning process, planning for learning, monitoring the learning task, and evaluating how well one has learned" (O'Malley \& Chamot, 1990:137). Both learner autonomy and meta-cognitive strategies focus on learner self-management and both are regarded as a means to help learners become more successful in their learning. There is a convergence between them. Wenden $(1995,1998)$ states that learners make use of meta-cognitive strategies to monitor, manage and self-direct their own learning; and planning, monitoring, and evaluation are three main strategies identified in the literature on autonomy in language learning and selfregulation learning. In the light of this, training learners in meta-cognitive management strategies, which appears to be more learner-based, has been a key approach adopted in this research to promote learner autonomy.

\section{B. Learning Strategy Instruction Model}

O'Malley and Chamot summarize two approaches of learning strategy instruction-direct or embedded. In direct instruction, "students are informed of the value and purpose of strategy training"; whereas in embedded instruction, "students are presented with activities and materials structured to elicit the use of the strategies being taught but are not informed of the reasons why this approach to learning is being practiced" (O’Malley \&Chamot, 1990). Yet embedded training has been criticized by Wenden (1987), who claims that in embedded training, students without an awareness of the strategies being used can not develop independent learning strategies and have little opportunity of becoming autonomous learners.

Based on investigating current issues in language learning strategy research and teaching, Chamot (2004) proposes a model for language learning instruction-Cognitive Academic
Language Learning Instruction (CALLA). This approach aims to "developing students' knowledge about their own thinking and strategic processes and encouraging them to adopt strategies that will improve their language learning and proficiency" (Chamot, 2004). The framework of this approach is a six-phase recursive cycle for introducing, teaching, practicing, evaluating, and applying learning strategies.

- Preparation: Teachers identify students' current learning strategies for familiar tasks.

- Presentation: Teacher models, names, explain new strategy; asks students if and how they have used it.

- Practice: Students practice new strategy; in subsequent strategy practice, teachers fade as reminders to encourage independent strategy use.

- Self-evaluation: Students evaluate their own strategy use immediately after practice.

- Expansion: Students transfer strategies to new tasks, combine strategies into clusters, develop repertoire of preferred strategies.

- Assessment: Teachers assess students' use of strategies and impact on performance (Chamot, 2004).

This model will be adopted in this thesis to design metacognitive strategy training tasks. Following the steps of CALLA, the teacher train students to get into the habit of analyzing learning needs, planning learning objectives, organizing learning tasks, monitoring learning process, and evaluating learning outcomes. Therefore, they can gradually become autonomous learners.

\section{RESEARCH DESIGN}

\section{A. Purpose}

The research attempts to answer the following questions:1) Does meta-cognitive strategy training lead to Vocational students' learning proficiency? 2) Does meta-cognitive strategy training result in vocational students' higher metacognitive strategy use?3) Is meta-cognitive strategy training effective to improve vocational students' learner autonomy?

\section{B. Subject}

The subject consisted of non-English freshmen of two vocational classes majoring in Clinical Medicine Specialty of Huanghe Science \& Technology (S\&T) College, a private college. Both EC and CC were appointed to use the fourth version of Century English Comprehensive Course One as the text book, edited by Gong Yao, and published by Dalian University of Technology Press. Both of the two classes took four classes per week, given by the author of the present thesis. The EC was taught with meta-cognitive strategy training, while the $\mathrm{CC}$ received traditional teaching method. The research was conducted from September, 2012 to the end of January, 2013, a whole semester. 


\section{Instruments}

The research contained quantitative study and qualitative study. In the quantitative study, the instruments applied included two placement tests and one questionnaire. In the qualitative study, learner profiles, journals and interviews as well as teachers' observations are used to collect data.

\section{1) Instruments for the quantitative study.}

a) Pre-test and Post-test: Students' English scores of college entrance exams in 2012 were taken as pre-test and the final exam scores in January 2013 after almost 15 weeks experiment were set to be the post-test.

b) Questionnaire: The questionnaire which was used twice in this experiment was applied to see the changes of students' learner autonomy and meta-cognitive strategy use. The investigation questionnaire was initially designed by $\mathrm{Xu}$ Jinfen and Peng Renzhong (2004), which is based on three theoretical foundations.

\section{2) Instruments for the qualitative study.}

a) Learner Profile: A learner profile is a collection of information relating to an individual learner. The students of EC were asked to make learner profiles which included five aspects.

- Recording your needs and wants.

- Using a contract to state the goals aiming at during a specific period of time in the form.

- Making detailed plans to achieve your goals.

- Recording of your learning achievement from selfassessment, peer assessment or teachers' views.

- Reflections on teacher's intervention and your learning process.

The learner profiles were collected every two weeks, and the teacher made comments on them as a communication between the teacher and the students.

b) Interviews: Interviews provide opportunity for indepth probing, elaboration, and clarification. The interviewees were students in the EC class with different English proficiency. They were interviewed after class in Chinese informally so as to get more truthful and reliable information. The main topics of the interview focus on the eight aspects of the questionnaire. The information was later noted down by the author.

c) Teacher's logs: Teacher's logs mainly noted down classroom observation and information collected from the students' profiles, interviews. They also served as a way to monitor students' learning progress.

\section{Procedures of the Research}

The procedures of the research consist of a pilot study, phase one and phase two.
1) Pilot study: The pilot study was undertaken to confirm the effectiveness of the questionnaire. According to the result, the questionnaire was revised on wording, content, and printing pattern to ensure their validity and reliability with the help of a group of teachers who have knowledge of the study as well as the instrument design.

\section{2) Phase one.}

a) Making of learner profiles: The first phase of the study began in the first week of the semester in September. After a brief lecture on learner autonomy and meta-cognitive strategy, students of the two classes majoring in clinical medicine were asked to take the questionnaires. The questionnaires were carefully collected and analyzed. According to the analysis on the English scores of their college entrance examination, class one was set to be EC, while class two was set to be CC. The students were not told about the classification. Based on the feedbacks of the questionnaires, the students of the EC were asked to make learner profiles with the teacher's guidance.

b) Dividing of groups for group monitoring: Effective monitoring affects the result of meta-cognitive training. With regard to the limitation of teacher's monitoring, group monitoring was applied in this research. Fifty-five students of the EC were divided into fourteen groups, in thirteen of which there were four students, and one of which included three students, on the basis of their English levels, personalities, genders and hometowns.

In order to monitor students' planning, and ensure implementation of their plans, each student was asked to submit a copy of his plan to the group. Then the group made a "Table I" of each member's plan and each kept a copy to ensure everyone knew clearly what other members planned to do during the week. So they can remind and check each other. Each member was given a self-questioning sheet for monitoring.

3) Phase two: Meta-cognitive strategy training: The second phase started in the third week of this semester with the implementation of meta-cognitive strategy training.

Meta-cognitive strategy mainly involves three steps: making learning plans, monitoring learning process, and evaluating learning outcomes. Making learning plan is the first step of meta-cognitive strategy training. Based on students' college entrance exams and the analysis on their questionnaires, the students made their learner profiles which included their long-tern plans and weekly plans. The author served as the counselor and facilitator. The students' long-term goals mainly consisted of two aspects: one is to pass exams, including CET4, upgrade English test, and their final exams; the other was to improve their specific English skills, like writing, reading and so on. Many students think enlarging vocabulary will greatly improve their English levels. The author introduced different strategies to memorize new words throughout vocabulary teaching in classes. As to the choosing of reading materials, the author gave suggestions on the content, new words rate, and the resources of the materials. With regard to the fact that learner profiles were made at the beginning of the term, the 
author asked students to make adjustments according to their learning processes.

Effective monitoring decides whether the meta-cognitive strategy training is successful or not, especially for vocational students who have more difficulties in implementing learning plans. This research mainly applied self-monitoring, peer monitoring through group cooperation and teacher's monitoring with the assistance of students' learner profiles. The self-questioning sheets were collected every month to ensure the effectiveness of peer-monitoring and selfmonitoring. The students' learner profiles were collected every two weeks and the author gave feedbacks as communication between students and the teacher. Every month, the teacher would hold discussions in class in order to communicate the problems in the learner profiles to students and gave suggestions for their further training.

Evaluation is defined as "the act of collecting information and making judgment on a language learner's understanding of a language and his ability to use it" (Nunan, 2002). Evaluation includes summative assessment and formative assessment. Summative assessment refers to standardized tests, while formative assessment is a form of assessment to enhance teaching and learning. The author used formative assessment in this research. In students' learner profiles, the author gave students descriptive feedback on their learning to inform students of their positive actions and their shortcomings that they needed to improve upon. Self-assessment and peerassessment were also applied to develop learners' capability of assessing the outcome of their own learning and also their peers' learning. In the learner profiles, there was space for learners to write down their reflections on the implementation of their plans. So they can reflect their learning effect and keep a record of their learn progress. During the group monitoring, the group members were also asked to exchange their assessment on each other regularly. The author also organized various class activities to help form supportive learning atmosphere to arouse students' initiative and avoid negative attitude toward criticism. Group discussions, role-plays, presentations are commonly ways to promote students' communication between each other.

\section{E. Data Collection and Processing}

At the end of the term, the same questionnaire was used again among the two classes and collected after the final examinations. The scores of $\mathrm{CC}$ and $\mathrm{EC}$ were collected as posttest. Both the questionnaire and the posttest's results were analyzed with SPSS17.0. Independent-sample t-test and paired-sample t-test were applied to check if there was significant difference between EC and CC after the experiment.

\section{RESULTS AND DISCUSSION}

This chapter focuses on the results gained from the statistic analysis of the data from samples and findings of the research.

\section{A. Descriptions of Research Question One}

This part answers the question "does meta-cognitive training lead to learning proficiency?"
1) Selection of experimental group and control group: At the beginning of the study, the researcher collected the subjects' college entrance English scores as the pretest data. By analyzing the data through Independent Samples T-Test and Group Statistics of Pre-test Scores, the research attempted to find if there were significant differences between class 1 and class 2 .

From "Table I", we can see class 1' Stand Deviation is 18.974, which is quite close to that of class 2 ' 17.595 . The mean score of Class 1 in the pretest is 55.62, and that of Class 2 in the pretest is 59.20. The mean score of Class 2 is 3.58 higher than that of Class 1. Although the difference is not significant, with regard to the effect of the empirical research, class 1 with 55 students is set as the experimental class shorted as EC, and class 2 with 50 students is set as the controlled class abbreviated as $\mathrm{CC}$.

TABLE I. GRouP STATISTICS OF PRE-TEST SCORES BETWEEN THE Class 1 AND Class 2

Group Statistics

\begin{tabular}{|cc|l|l|l|l|}
\hline & $\begin{array}{c}\text { num } \\
\text { ber }\end{array}$ & $\mathbf{N}$ & Mean & \multicolumn{1}{c|}{$\begin{array}{c}\text { Std. } \\
\text { Deviation }\end{array}$} & $\begin{array}{c}\text { Std. Error } \\
\text { Mean }\end{array}$ \\
\hline pretest & $\mathbf{1}$ & 55 & 55.62 & 18.974 & 2.558 \\
& $\mathbf{2}$ & 50 & 59.20 & 17.595 & 2.488 \\
\hline
\end{tabular}

The above "Table II" shows that Sig value is 0.368 which is much higher than 0.05 , so the two variances are equal. Sig (2-tailed) value is 0.320 , which means the significance probability of the pre-tests score is $30 \%$. At the same time, the $95 \%$ Confidence Interval of the Difference includes " 0 " between the lower value which is -10.686 and the upper value which is 3.52 . That is to say, the means of two classes' pretests is not significantly different. So there is not significant difference between the pretests of the two classes.

2) Comparison of EC and CC in Post-test: The scores of EC and CC' final exams were collected and analyzed through SPSS 17.0 to compare whether there were significant differences between EC and CC after one term's metacognitive training. Independent sample t-test and paired sample t-test were used to make the analysis more scientific and clearer. 
Independent Samples Test

\begin{tabular}{|c|c|c|c|c|c|c|c|c|c|c|}
\hline & & \multicolumn{2}{|c|}{$\begin{array}{c}\text { Levene's Test } \\
\text { for Equality of } \\
\text { Variances }\end{array}$} & \multicolumn{7}{|c|}{ t-test for Equality of Means } \\
\hline & & \multirow[b]{2}{*}{$\mathrm{F}$} & \multirow[b]{2}{*}{ Sig. } & \multirow[b]{2}{*}{$\mathrm{t}$} & \multirow[b]{2}{*}{ df } & \multirow[b]{2}{*}{$\begin{array}{l}\text { Sig. } \\
\text { tailed })\end{array}$} & \multirow[b]{2}{*}{$\begin{array}{l}\text { Mean } \\
\text { Difference }\end{array}$} & \multirow[b]{2}{*}{$\begin{array}{l}\text { Std. Error } \\
\text { Difference }\end{array}$} & \multicolumn{2}{|c|}{$\begin{array}{l}\text { 95\% Confidence Interval of } \\
\text { the Difference }\end{array}$} \\
\hline & & & & & & & & & Lower & Upper \\
\hline pretest & $\begin{array}{l}\text { Equal variances } \\
\text { assumed } \\
\text { Equal variances not } \\
\text { assumed }\end{array}$ & .816 & .368 & $\begin{array}{l}-1.000 \\
-1.004\end{array}$ & $\begin{array}{l}103 \\
102.956\end{array}$ & $\begin{array}{l}.320 \\
.318\end{array}$ & $\begin{array}{l}-3.582 \\
-3.582\end{array}$ & $\begin{array}{l}3.582 \\
3.569\end{array}$ & $\begin{array}{l}-10.686 \\
-10.660\end{array}$ & $\begin{array}{l}3.522 \\
3.496\end{array}$ \\
\hline
\end{tabular}

From "Table III", we can see the EC's mean score is 74.636, while the CC's mean score is 67.173. The EC's mean score is 7.4629 higher than CC.

TABLE III. GROUP STATISTICS OF THE POSTTEST SCORES OF THE EC AND THE CC WITH INDEPENDENT S AMPLE T-TEST

\begin{tabular}{|ll|l|l|l|l|}
\hline & class & N & Mean & $\begin{array}{c}\text { Std. } \\
\text { Deviation }\end{array}$ & $\begin{array}{c}\text { Std. Error } \\
\text { Mean }\end{array}$ \\
\hline $\begin{array}{l}\text { posttes } \\
\mathrm{t}\end{array}$ & 1 & 55 & 74.636 & 13.0889 & 1.7649 \\
& 2 & 50 & 67.173 & 11.2738 & 1.6105 \\
\hline
\end{tabular}

The above "Table IV" shows that Sig value is 0.083 which is higher than 0.05 , so the two variances are equal. Sig (2tailed) value is 0.003 , which is lower than 0.05 . That means the mean score of EC and CC are significantly different. At the same time, there is not " 0 " between the lower value 2.6826 and the upper value 12.2431, which confirms that EC and CC's posttests are of significant difference.

So after one term's meta-cognitive strategy training, the scores of EC are improved much more than that of CC class. That is to say, carrying out effective meta-cognitive strategy training will lead to better language proficiency.

TABLE IV. INDEPENDENT S AMPLE T-TEST OF THE POSTTEST SCORES OF THE EC AND THE CC

\begin{tabular}{|c|c|c|c|c|c|c|c|c|c|c|}
\hline & \multicolumn{2}{|c|}{$\begin{array}{l}\text { Levene's Test } \\
\text { for Equality of } \\
\text { Variances }\end{array}$} & \multicolumn{7}{|c|}{ t-test for Equality of Means } \\
\hline & & \multirow[b]{2}{*}{$\mathrm{F}$} & \multirow[b]{2}{*}{ Sig. } & \multirow[b]{2}{*}{$\mathrm{t}$} & \multirow[b]{2}{*}{$\mathrm{df}$} & \multirow[b]{2}{*}{$\begin{array}{l}\text { Sig. } \\
\text { tailed })\end{array}$} & \multirow[b]{2}{*}{$\begin{array}{l}\text { Mean } \\
\text { Difference }\end{array}$} & \multirow[b]{2}{*}{$\begin{array}{l}\text { Std. Error } \\
\text { Difference }\end{array}$} & \multirow{2}{*}{$\begin{array}{l}95 \% \\
\text { Interval } \\
\text { Difference } \\
\\
\text { Lower }\end{array}$} & $\begin{array}{l}\text { Confidence } \\
\text { of the }\end{array}$ \\
\hline & & & & & & & & & & Upper \\
\hline & $\begin{array}{l}\text { Equal variances not } \\
\text { assumed }\end{array}$ & & & 3.123 & 101.892 & .002 & 7.4629 & 2.3893 & 2.7237 & 12.2021 \\
\hline
\end{tabular}

\section{B. Description of Research Question Two}

This part tried to answer research question two "does meta-cognitive strategy training result in higher metacognitive strategy use?"

The questionnaire consists of 50 questions. According to the classification of the questionnaires, the questions are divided into eight aspects including: A. students' beliefs on learning responsibilities; B. students' self-motivation on learning; C. students' knowing and understanding of the teacher's teaching objectives and requirements; D. students' setting of learning objectives and plans; E. students' using of learning strategies; F. students' monitoring of learning strategies use; G; students' monitoring of learning process; $\mathrm{H}$. students' evaluating of learning process and result. A fivepoint Likert scale 5, 4, 3, 2, 1 is used in the questionnaire. All the items are designed in positive direction and all orders of the answers are put in one direction except 7 and 46 . In order to ensure the reliability and validity of the questionnaire analysis, the input of 7 and $46^{\prime}$ scores is different from others.

Meta-cognitive strategy mainly consists of planning, monitoring and evaluating, and monitoring refers to the monitoring on both meta-cognitive strategy use and learning process. According to the design of the questionnaire, the four parts marked as D, F, G and $\mathrm{H}$ were selected to analyze to investigate EC and CC's meta-cognitive strategy use.

1) Comparison between EC and CC'pre-questionnaires on meta-cognitive strategy use: EC's pre- and postquestionnaire data were applied to analyze through SPSS 17.0, the results are shown in the following "Fig. 1". 


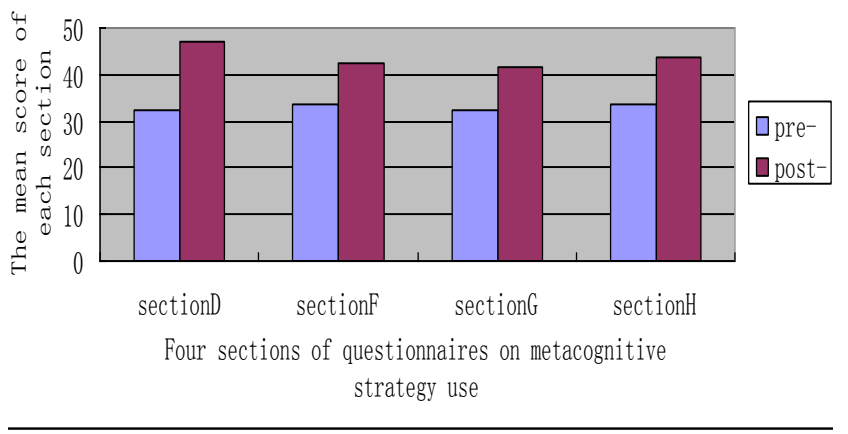

Fig. 1. The Comparison of the Mean Scores of section D, F, G and H in EC' pre and Post Questionnaires

From the "Fig. 1", we can see EC' meta-cognitive strategy use is generally improved after meta-cognitive strategy training. The scores of the four sections are increased in different degrees. The total mean score for each section is 50. Students abilities of goal-setting and planmaking represented as section $\mathrm{D}$ are improved more obviously than the other three aspects from 32.36 to 46.73 . That means the meta-cognitive strategy straining on goalsetting and plan-making are effective. With the assistance and guidance of the researcher, students get into the habit of making plans. Students' abilities of monitoring strategy use and learning process are improved. The score of strategy monitoring is improved from 33.44 to 42.53 , and the score of learning process monitoring is improved from 32.41 to 41.72 . That shows the combination of teacher, self and group monitoring is effective.

2) Comparison between EC and CC' postquestionnaires on meta-cognitive strategy use: The author also analyzed the mean score of section D, F, G and $\mathrm{H}$ of $\mathrm{EC}$ and CC's post-questionnaires in order to compare whether the EC and $\mathrm{CC}$ have obvious difference in metacognitive strategy use after the training. The results are shown in the following "Fig. 2".

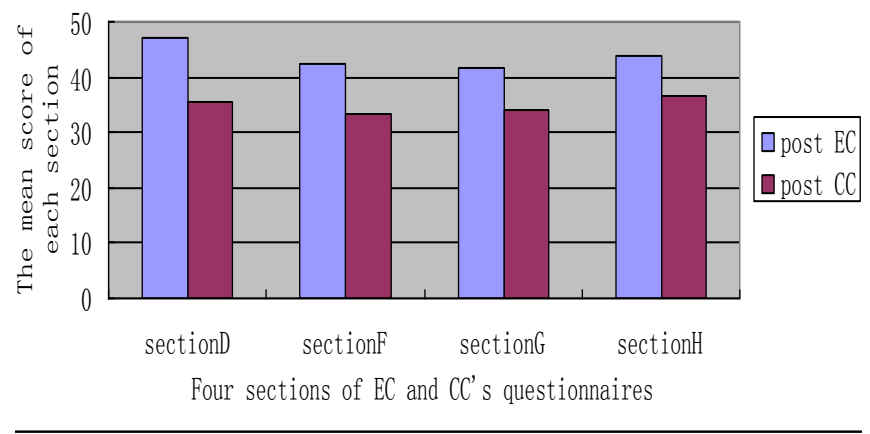

Fig. 2. The Comparion of the Mean Scores of Section D, F, G and H in EC and CC's Questionnaires.

According to the "Fig. 2", generally speaking, the scores of the four aspects of EC are all much higher than that of CC after one term's meta-cognitive strategy training. That means EC's meta-cognitive strategy uses are much better than $\mathrm{CC}$. That keeps consistent with the result of EC and CC's post- test analysis. That also proves the meta-cognitive strategy training is effective.

\section{Descriptions of Research Question Three}

This part attempts to answer "is meta-cognitive strategy training effective in facilitating learner autonomy?" The mean score of the eight parts are precisely calculated before they are analyzed through SPSS 17.0.

1) Comparison of EC and CC in pre-questionnaires on learner autonomy: To answer this question, data from EC and CC's pre- and post- questionnaires were analyzed through independent sample t-test and paired sample t-test. So we have the following "Table V".

Independent Sample T-tests for Learner Autonomy in Pre-questionnaires between EC and CC.

TABLE V. GROUP STATISTICS

\begin{tabular}{|ll|c|c|c|c|}
\hline & class & $\mathbf{N}$ & Mean & $\begin{array}{c}\text { Std. } \\
\text { Deviation }\end{array}$ & $\begin{array}{c}\text { Std. Error } \\
\text { Mean }\end{array}$ \\
\hline premean & 1 & 8 & 3.374784 & .3558328 & .1258059 \\
& 2 & 8 & 3.358320 & .3680332 & .1301194 \\
\hline
\end{tabular}

From the "Table V", we can see every part's mean score of EC' questionnaires is 3.374784, which is 0.0164639 higher than 3.358320 of CC's questionnaires.

According to the "Table VI", the Sig value is 0.907 which is higher than 0.05 , so the two variances are equal. The Sig (2-tailed) value is 0.929, which is higher than 0.05 . That means the mean score of EC and CC's questionnaires are not significantly different. At the same time, there is " 0 " between the lower value 2.6826 and the upper value 12.2431 , which confirms that the mean score of EC and CC's prequestionnaires are not of significant difference. So EC and CC didn't have significant difference in learner autonomy before meta-cognitive strategy training. 
TABLE VI. INDEPENDENT S AMPLES TEST

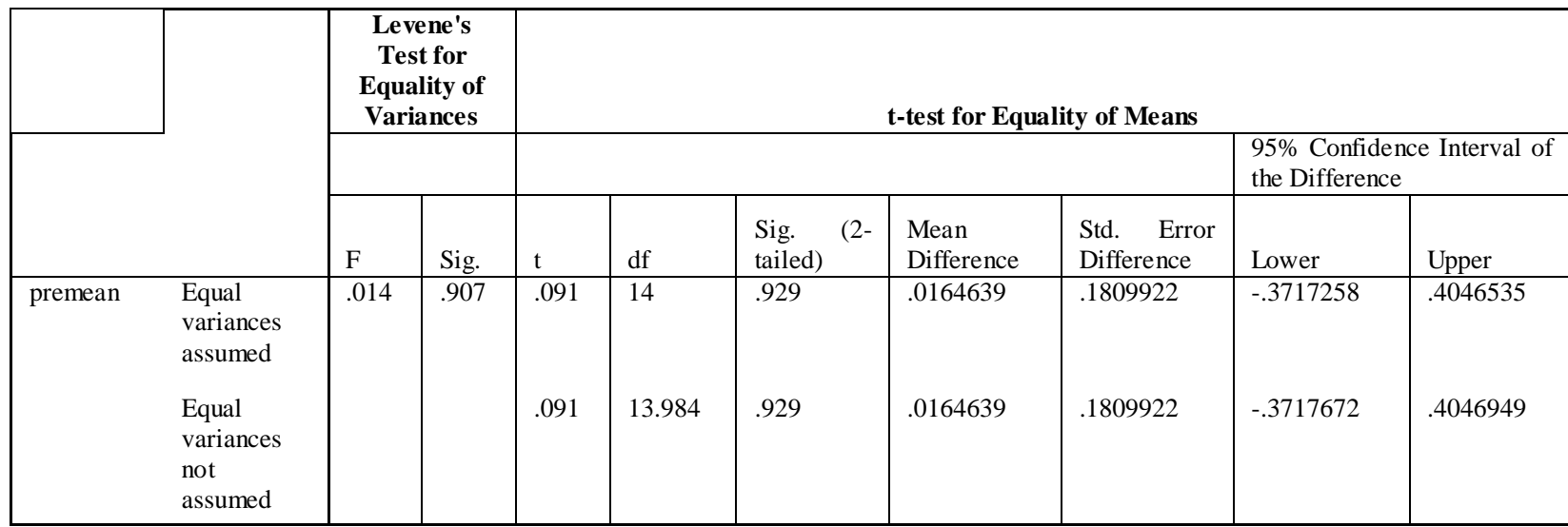

2) Comparison between EC and CC in Postquestionnaires: At the end of the meta-cognitive strategy training, the same questionnaires were used again, and data were collected and analyzed. The result is as follows "Table VII".

TABLE VII. GROUP STATISTICS

\begin{tabular}{|ll|l|l|l|l|}
\hline & class & \multicolumn{1}{|c|}{$\mathbf{N}$} & \multicolumn{1}{|c|}{ Mean } & \multicolumn{1}{|c|}{ Std. Deviation } & \multicolumn{1}{c|}{ Std. Error Mean } \\
\hline postmean & 1 & 8 & 4.235913 & .3050512 & .1078519 \\
& 2 & 8 & 3.358320 & .3680332 & .1301194 \\
\hline
\end{tabular}

The above "Table VII" shows EC's every part's mean score is 4.235913 , while CC's every part's mean score is 3.358320 . EC's every part's mean score is 0.8775923 higher than that of CC. However, we can not draw the conclusion that there is significant difference between EC and CC in post-test. So we need to see the Independent Sample T-test to make it clear.

Independent Sample T-test for learner Autonomy in Posttest between EC and CC.
According to the "Table VIII", the Sig value is 0.640 which is higher than 0.05 , so the two variances are equal. The Sig (2-tailed) value is 0.000 , which means the significant probability of EC and CC are $100 \%$ different as to every part of their questionnaires' mean score. That means EC's learner autonomy is much higher than CC's. So after one term's meta-cognitive strategy training, EC' learner autonomy has improved significantly. That is to say, carrying out effective meta-cognitive strategy training will improve learner autonomy.

TABLE VIII. INDEPENDENT SAMPLES TEST

\begin{tabular}{|c|c|c|c|c|c|c|c|c|c|c|}
\hline & \multicolumn{2}{|c|}{$\begin{array}{c}\text { Levene's Test for } \\
\text { Equality of } \\
\text { Variances }\end{array}$} & \multicolumn{7}{|c|}{ t-test for Equality of Means } \\
\hline & & \multirow[b]{2}{*}{$\mathrm{F}$} & \multirow[b]{2}{*}{ Sig. } & \multirow[b]{2}{*}{$\mathrm{t}$} & \multirow[b]{2}{*}{$\mathrm{df}$} & \multirow[b]{2}{*}{$\begin{array}{l}\text { Sig. } \\
\text { tailed })\end{array}$} & \multirow[b]{2}{*}{$\begin{array}{l}\text { Mean } \\
\text { Difference }\end{array}$} & \multirow[b]{2}{*}{$\begin{array}{l}\text { Std. Error } \\
\text { Difference }\end{array}$} & \multicolumn{2}{|c|}{$\begin{array}{l}\text { 95\% Confidence Interval of } \\
\text { the Difference }\end{array}$} \\
\hline & & & & & & & & & Lower & Upper \\
\hline postmean & $\begin{array}{ll}\text { Equal } & \text { variances } \\
\text { assumed } & \end{array}$ & .228 & .640 & 5.193 & 14 & .000 & .8775923 & .1690062 & .5151101 & 1.2400744 \\
\hline & $\begin{array}{l}\text { Equal variances not } \\
\text { assumed }\end{array}$ & & & 5.193 & 13.534 & .000 & .8775923 & .1690062 & .5139362 & 1.2412483 \\
\hline
\end{tabular}

\section{CONCLUSION}

\section{A. Major Findings}

Based on the analysis of previous chapters, some major findings are summarized as follows.

- Meta-cognitive strategy training can promote consciousness and abilities of meta-cognitive strategy use. The pre-questionnaire analysis shows that vocational students have moderate learning responsibilities, but they have weak abilities of using cognitive and meta-cognitive strategies. The mean score of learning responsibility part in EC's prequestionnaires is 3.98; while the mean score of investigation on learning strategy use in EC's prequestionnaires is 2.85 . So most of them are willing to learn, but are lack of sui "Table I" learning strategies. It's necessary to carry out cognitive and metacognitive strategy training. 
- Goal-setting and plan-making can inspire students to connect teachers' teaching objectives with their own learning needs and aims. That can encourage students to be better involved in class learning. Most vocational students pay no attention to the teacher's teaching objectives and aims, which hinders their learning efficiency. They are not clear about the objectives of their class activities, so they can not well apply relevant strategies and evaluate their learning effect. That also affects their learning initiative to participate in the teacher's lecture. So it is important to help vocational students better understand teacher's teaching objectives and aims in classroom learning.

- Specific learning plan forms provided by the teacher are necessary and important for vocational students to imitate as models. Most vocational students have difficulty in setting goals and making continual learning plans. They don't have clear knowledge of their learning needs and wants. They don't have the habit and experience of making specific plans. So at the beginning of the meta-cognitive training, the teacher plays an important role in assisting students to set reasonable goals and making proper plans.

- Students' learner profiles are quite useful in keeping track of students' learning progress. It also serves as a tool for communication between the teacher and students. The reflective parts of learner profile boost students to reflect on their learning continuously and greatly improve their reflective ability in learning.

- Group monitoring is effective in complementing the shortcomings of teacher and self monitoring. Cooperative activities are helpful in forming good cooperative spirit and learning atmosphere, which are the foundation for group monitoring. Self questioning sheet can well remind students of carrying out their monitoring responsibilities in the long meta-cognitive training. Effective monitoring leads to the success of meta-cognitive strategy training.

\section{B. Implications and Recommendations for Further} Researches

- The vocational students are willing to accept autonomous learning, but their weak abilities in learner autonomy and English decide the importance of teacher's roles in promoting learner autonomy. Teachers serve as counselor, resource provider, organizer, assessor, and evaluator and so on. So in order to improve students' learner autonomy, it's necessary to do more researches on how to improve teacher autonomy.

- This research took the whole class as a sample to analyze the questionnaire and test score, but it is supposed that students of varying English levels may react differently to meta-cognitive strategy training. So if the researcher took students of different English levels within the same class as samples to analyze, more specific and valuable results may be seen. That may bring about the application of better training practices.

On the whole, there is not any definite mode to carry out meta-cognitive strategy training in promoting learner autonomy, but with more and more empirical researches, there will be more systematic operational theories leading to better training effect. This paper is expected to serve as a stepping stone for future researches on better meta-cognitive strategy training in facilitating learner autonomy.

\section{REFERENCES}

[1] Benson, P. Autonomy in language teaching and learning. Language Teaching, 2007, ( 1) : $21-40$.

[2] Benson, P, \& Voller, P. Autonomy and independence in language learning $[\mathrm{M}]$. New York.

[3] He Lianzhen, Fu Ying, Fang Fumin, Min Shangchao, An Exploration on Promoting Non-English Major's Learner Autonomy, Foreigh Languages in China,2011, (05) 18-24. 